\title{
CIB1 Gene
}

National Cancer Institute

\section{Source}

National Cancer Institute. CIB1 Gene. NCI Thesaurus. Code C106107.

This gene plays a role in cell adhesion, megakaryocyte differentiation, apoptosis regulation and calcium binding. 